\title{
Drug-micronutrient interactions: food for thought and thought for action
}

\author{
Vasiliki Karadima', Christina Kraniotou', George Bellos ${ }^{1}$ and George Th. Tsangaris ${ }^{2^{*}}$
}

\begin{abstract}
Micronutrients are indispensable for a variety of vital functions. Micronutrient deficiencies are a global problem concerning two billion people. In most cases, deficiencies are treatable with supplementation of the elements in lack. Drug-nutrient interactions can also lead to micronutrient reduce or depletion by various pathways. Supplementation of the elements and long-term fortification programs for populations at risk can prevent and restore the related deficiencies. Within the context of Predictive, Preventive, and Personalized Medicine, a multiprofessional network should be developed in order to identify, manage, and prevent drug-micronutrient interactions that can potentially result to micronutrient deficiencies.
\end{abstract}

Keywords: Predictive preventive personalized medicine, Micronutrients, Micronutrient deficiency, Epidemiology, Drug-nutrient interactions, Multi-professional network, Advanced health care, Well-being

\section{What are micronutrients?}

Micronutrients [1] is a term generally used to define all essential vitamins and minerals mainly taken from food sources and which are necessary for vital functions [2,3]. Micronutrients consist only of $0.01 \%$ of body mass [1]. Surprisingly, even if the amounts required are very low, a lack of micronutrient can lead to severe, non-ignorable health disorders, even threatening for life [2]. Fortunately, most of these dysfunctions can disappear after the administration of the elements in lack [3].

\section{What about epidemiology?}

Micronutrient deficiencies (MNDs) are a very common condition. It is estimated that about two billion people in the world suffer from MNDs [2]. Notably, this is not a problem of developing countries exclusively [4]. Many people in west societies are diagnosed with MNDs [4]. However, in these countries, MNDs often remain undiagnosed and are supposed to affect 1 in 3 persons [3]. Malnutrition is the major cause of MNDs [3], and it may include low intake or malabsorption of micronutrients owing to infection, inflammation, or a systematic disease [2]. Pregnant women, children less than 5 years of age,

\footnotetext{
* Correspondence: gthtsangaris@bioacademy.gr

${ }^{2}$ Proteomics Research Unit, Biomedical Research Foundation of the Academy of Athens, Athens, Greece

Full list of author information is available at the end of the article
}

and elderly people are more likely to suffer from any type of MNDs [2]. The most frequent deficiency is that of iron [1], followed by vitamin A, folate, iodine, and zinc deficiency [3]. In minors, vitamin and folate deficiencies dominate across all age groups [4]. Appearance of multiple MNDS is more common than that of sole [2]. Table 1 describes selected micronutrient deficiencies and their clinical manifestations and diagnosis.

\section{But how micronutrient status can be determined?}

Modern methods are currently used to count the amount of a micronutrient in the body. The most accurate method is metabolites biomarkers [1], which count micronutrient levels using blood or urine samples [2]. The functional intracellular analysis-within lymphocytes in blood samples or buccal mucosa cells-is a novel (part of -omics science) reliable process of micronutrient testing [5-7].

\section{How MNDs can be faced?}

MNDs can be prevented massively by the fortification of elements in lack in a country or region. Preventive programs are often applied to population at risk. The most common example is the enrichment of table salt carried forward by many governments. On the other hand, population groups at risk may receive supplementation according to guidelines. For instance, iron and folic acid are prescribed to pregnant women [2]. 
Table 1 Selected micronutrients: role, signs, and symptoms of deficiencies and accurate diagnosis

\begin{tabular}{|c|c|c|c|}
\hline Micronutrient & Functions & Symptoms and signs of deficiency & Diagnosis \\
\hline Iron & $\begin{array}{l}\text { Constituent of hemoglobin, carries out oxygen } \\
\text { transport, indispensable for cognitive functions }\end{array}$ & $\begin{array}{l}\text { Anemia, endocrine and immune disorders, } \\
\uparrow \text { danger for maternal death } \\
\text { Newborns: } \downarrow \text { birthweight, prematurity, perinatal } \\
\text { complications, physical and mental retardation }\end{array}$ & $\begin{array}{l}\text { At least } 2 \text { of } 3 \text { : } \\
\downarrow \text { Hemoglobin } \\
\downarrow \text { Ferritin } \\
\downarrow \text { Transferrin saturation }\end{array}$ \\
\hline Vitamin A & $\begin{array}{l}\text { Participates in vision, immunization, reproduction, } \\
\text { growth }\end{array}$ & $\begin{array}{l}\text { Sensitivity, infections, xerophthalmia and other } \\
\text { vision problems, blindness in children }\end{array}$ & $\begin{array}{l}\downarrow \text { Serum retinol, ophthalmologic } \\
\text { examination }\end{array}$ \\
\hline lodine & $\begin{array}{l}\text { Constituent of thyroid hormone, CNS growth } \\
\text { in fetus and infant }\end{array}$ & $\begin{array}{l}\text { Fetus: neurological and mental retardation } \\
\text { (permanent), cretinism } \\
\text { Adult: goiter, } \downarrow \text { mental function, hypo/ } \\
\text { hyperthyroidism }\end{array}$ & $\downarrow$ Urine iodine \\
\hline Folate & $\begin{array}{l}\text { Constituent of vitamin B, participates in DNA } \\
\text { synthesis, stability, and repair, disinclines mutations }\end{array}$ & $\begin{array}{l}\text { Megalosblastic-macrocytic anemia } \\
\text { Fetus: neural tube defects }\end{array}$ & $\begin{array}{l}\downarrow \text { Concentration in serum, } \\
\text { plasma, and erythrocytes }\end{array}$ \\
\hline Zinc & $\begin{array}{l}\text { Activates enzymes involved in immunization, } \\
\text { necessary for fetus and children growth }\end{array}$ & $\begin{array}{l}\uparrow \text { Morbidity and mortality of diarrhea, } \\
\text { respiratory infection, and malaria }\end{array}$ & $\begin{array}{l}\text { No reliable biomarker due to } \downarrow \\
\text { bio-ability }\end{array}$ \\
\hline
\end{tabular}

For example, iron is an essential element for oxygen transportation, the red blood cells, and several enzymes' production and important immune functions. Its deficiency that affects millions lies hidden of the overall death rates, maternal hemorrhage, reduced mental, and physical performance. Reduced levels of blood hemoglobin, serum ferritin, and low transferrin saturation confirm the diagnosis of iron deficiency

In modern societies, the increase of life-span leads to multi-morbidity and inevitably to polypharmacy. Polypharmacy added to inappropriate drug prescribing increases the risk of drug-drug and drug-nutrient interactions (DNIs) [8-10]. DNIs are not rare, with the potential for over 300 remedies capable of interacting with nutrient or food components [11]. MNDs can be the adverse effect of these interactions, especially in elder and chronically ill people with impaired nutritional status.

\section{Drug-nutrient interactions}

The term DNIs refers to physicochemical, physiological, or pathophysiological relationships between a drug and a nutrient [12] or, in a broad sense, between a drug and multiple nutrients, food or components, or nutritional status $[13,14]$. DNIs can be classified in four types: type $I$, ex vivo bio-inactivation; type II, decreased/increased absorption; type III, decreased/increased effect; and type $I V$, decreased/increased clearance $[8,9,12]$.

A clinically significant drug-nutrient interaction is one related to an impaired physiologic process (quantifiable alteration of the kinetic and/or dynamic profile of a drug or a nutrient), which may result to malnutrition, therapy failure, adverse events, or even a life-threatening situation $[8,13]$. Factors that may enhance the type and intensity of DNIs include patient-related variables as age, sex, comorbidities, nutritional status, and also drug- and nutrient-associated factors as route of administration, nutrient status, and pharmacological/toxicological profile of the drug $[8,9$, 13] (Fig. 1). Some of the effects that commonly used drugs can have on micronutrient homeostasis are described in the Table 2.

\section{How DNIs can be addressed?}

Physicians must coordinate with nutritionists, nurses, and pharmacists in order to minimize DNIs and adverse outcomes. A comprehensive strategy can be planned, based on their knowledge, experience, and skills. Awareness of drug interactions with common dietary agents, defined drug administration schedules, periodic review of current drug therapy and dietary habits, proper education of health-care providers, and computerized drug interaction screening and warning software combined with patient counseling are crucial steps of this innovative approach $[9,10,15]$.

\section{Conclusion}

MNDs can be the result of malnutrition or the adverse outcome of common DNIs. In order to handle effectively MNDs and DNIs, modern health-care services should be governed by the principles of PPPM. PPPM uses advanced science technologies (genomic, proteomic, and metabolomics biomarkers or bio-predictors) that allow to determine individual predisposition to a particular illness and prevent clinically established dys-homeostasis, by using personalized, preventive, and therapeutic strategies [16, 17]. According to the National Institute of Health $(\mathrm{NIH})$ and other health authorities (European Commission, US Food and Agriculture Association (FDA), Centers for Disease Control and Prevention $(\mathrm{CDC}))$, PPPM constitutes a fundamental crucial axis of development in the twenty-first century [16]. The predictive branch of PPPM includes the identification and evaluation of new biomarkers/bio-predictors in subclinical stages of the pathological process before the onset of clinical manifestations [16, 17]. Pharmacogenomics and nutrigenomics are new research fields that study genedrugs and gene-nutrient interactions, aiming for the development of safe and effective drug-based therapies and the selection of health-promoting nutrients for individuals [18]. Accumulating data about the molecular mechanisms of DNIs will help us to generate a novel 


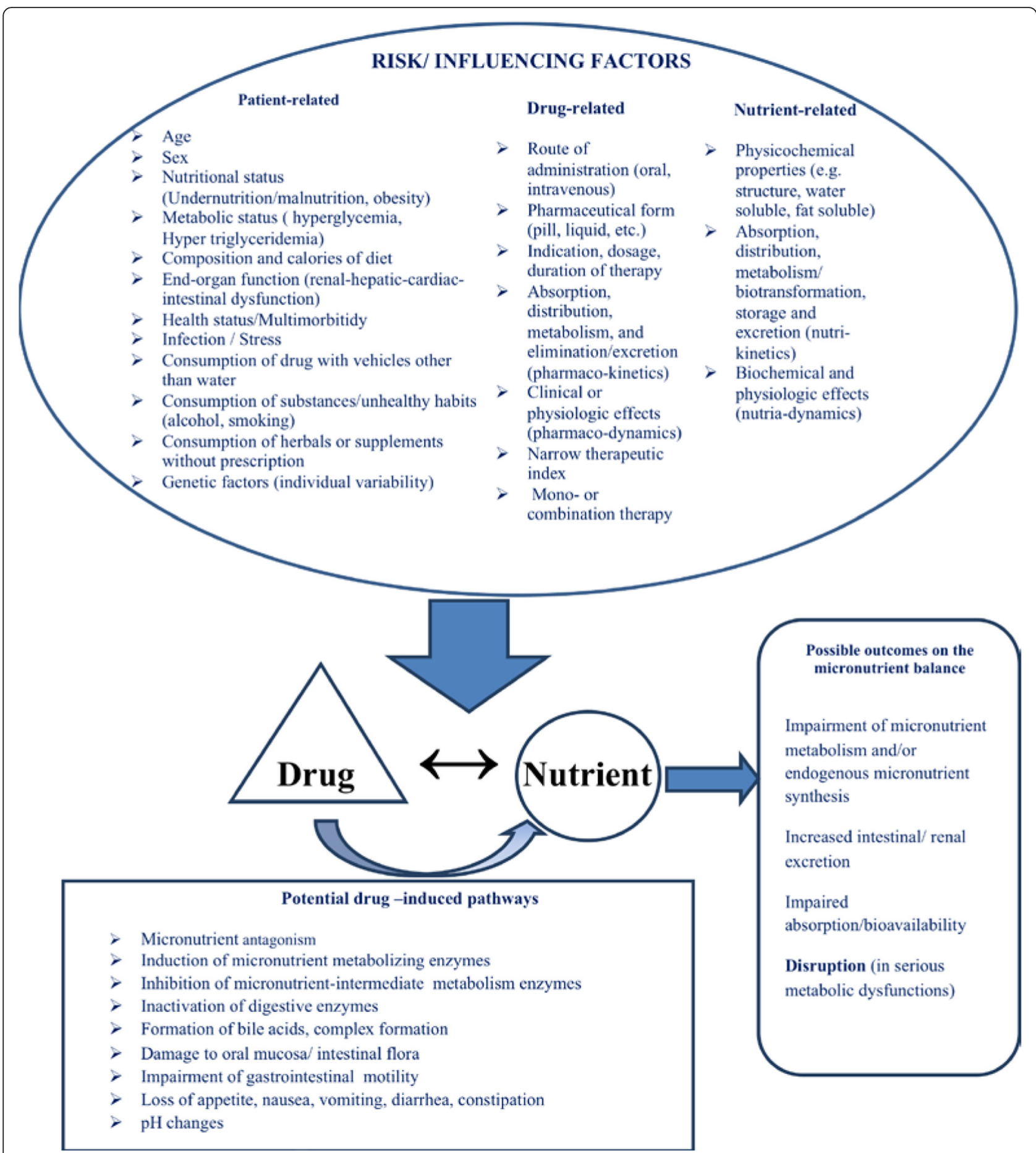

Fig. 1 Drug-nutrient interactions: influencing factors, possible pathways, and potential effects on the micronutrient balance. Risk for drug-nutrient interactions can be affected by many precipitating/influencing factors. These factors are related to individual characteristics (e.g., age, gender, medical history, genetic profile), remedies (pharmacokinetics, pharmacodynamics), and micronutrients properties (nutrikinetics, nutridynamics). Frequently, DNIs are bidirectional in their outcomes. Drugs can potentially influence the metabolism of micronutrients in multiple ways, from their intestinal absorption to their cell bioavailability. Intermediate pathways include a wide range of alterations in physiological processes such as increase in gastrointestinal motility (e.g., induced from metoclopramide, erythromycin, and cisapride) and thus limited absorption and increased nutrient loss. As a result, the micronutrient balance is affected and elimination may occur in severe and prolonged DNI, when a drug impairs/inhibits micronutrient absorption or metabolic functions 
Table 2 Drug-micronutrient interactions: widely used categories and possible drug-induced pathways that lead to nutrient depletions

\begin{tabular}{|c|c|c|}
\hline Widely used drugs (category) & Proposed mechanisms & (Micro) nutrient depleted \\
\hline Acid-suppressing and antacids & $\downarrow$ Absorption & $\begin{array}{l}\text { H2 antagonists } \\
\text { Calcium, iron, zinc, folic acid, vitamin D, and vitamin } B_{12} \\
\text { Proton-pump inhibitors (PPIs) } \\
\text { Vitamin } B_{12} \text { and magnesium }\end{array}$ \\
\hline Antibiotics & $\begin{array}{l}\downarrow \text { Absorption } \\
\text { Complex formation } \\
\text { Chelation } \\
\text { Enzyme induction } \\
\text { Mucosal block/damage } \\
\downarrow \text { Endogenous production }\end{array}$ & $\begin{array}{l}\text { Folic acid, iron, vitamin } A \text {, vitamin } D, B_{1} \text { (thiamin), } \\
B_{2} \text { (riboflavin), } B_{3}, B_{6}, B_{12} \text {, calcium, magnesium, } \\
\text { potassium, and vitamin } K\end{array}$ \\
\hline Anti-hypertensives & $\begin{array}{l}\downarrow \text { Cell availability } \\
\uparrow \text { Renal elimination }\end{array}$ & $\begin{array}{l}\text { Angiotensin-converting enzyme inhibitors: zinc } \\
\text { Calcium channel blockers: potassium } \\
\text { Chlorthalidone, hydrochlorothiazide, zinc, potassium, B vitamins } \\
\text { Loop diuretics: calcium, magnesium, potassium, zinc, } \\
\text { vitamins } B_{1} \text { and } B_{6} \\
\text { Hydralazine: vitamin } B_{6} \text { and coenzyme } Q_{10} \\
\text { Beta-blockers: coenzyme } Q_{10} \\
\text { Potassium-sparing diuretics: folic acid }\end{array}$ \\
\hline Antiepileptic drugs (anti-convulsants) & $\begin{array}{l}\downarrow \text { Absorption } \\
\uparrow \text { Metabolism } \\
\text { Enzyme induction } \\
\text { Chelation }\end{array}$ & $\begin{array}{l}\text { Barbiturates: calcium, folic acid, vitamins } D \text { and } K \\
\text { Phenytoin: calcium, folic acid, vitamins } B_{1}, B_{2} \text { and } D \\
\text { Carbamazepine: folic acid and vitamin D } \\
\text { Valproic acid: L-carnitine }\end{array}$ \\
\hline Psychotherapeutic drugs & $\begin{array}{l}\text { Enzyme induction } \\
\uparrow \text { Metabolism } \\
\downarrow \text { Endogenous production }\end{array}$ & $\begin{array}{l}\text { Selective serotonin reuptake inhibitors (SSRIs): folic acid } \\
\text { Benzodiazepines: melatonin, calcium } \\
\text { Tricyclic antidepressants, phenothiazines: coenzyme } \mathrm{Q}_{10} \\
\text { and vitamin } \mathrm{B}_{2} \\
\text { Haloperidol: coenzyme } \mathrm{Q}_{10}\end{array}$ \\
\hline Cholesterol-lowering drugs: statins & $\begin{array}{l}\downarrow \text { Cell availability } \\
\downarrow \text { Endogenous production }\end{array}$ & Coenzyme $\mathrm{Q}_{10}$, vitamin $\mathrm{D}$ \\
\hline Digoxin & $\uparrow$ Renal elimination & Magnesium, potassium, calcium, phosphorus, vitamin $\mathrm{B}_{1}$ \\
\hline Oral hypoglycemics & $\downarrow$ Absorption & Metformin: vitamin $B_{12}$ \\
\hline Oral contraceptives & $\begin{array}{l}\downarrow \text { Absorption } \\
\text { Enzyme induction }\end{array}$ & Vitamin $\mathrm{B}_{6}$, folic acid, magnesium \\
\hline Hormone replacement therapy (estrogens) & $\begin{array}{l}\downarrow \text { Absorption } \\
\uparrow \text { Metabolism } \\
\uparrow \text { Excretion }\end{array}$ & Vitamin $\mathrm{B}_{6}$, folic acid, magnesium \\
\hline Anti-inflammatory/analgesics & $\begin{array}{l}\downarrow \text { Absorption } \\
\downarrow \text { Cell availability }\end{array}$ & $\begin{array}{l}\text { Non-steroidal anti-inflammatory drugs: iron and folic acid } \\
\text { Salicylate: iron, folic acid, potassium, sodium, and vitamin C }\end{array}$ \\
\hline
\end{tabular}

For example, diuretics (anti-hypertensives) will possibly lead to a loss of micronutrients, especially of the water-soluble vitamins (vitamin $\mathrm{B}$ ) and minerals ( $\mathrm{K}$, Mg, $\mathrm{Ca})$, due to renal hyper-excretion. Some antibiotics can reduce the vitamin $\mathrm{K}$ synthesis by intestinal bacteria. Metformin, after long-term therapy, is associated with reduced vitamin $B_{12}$ levels by decreasing the uptake of $B_{12}$ via calcium-dependent ileal cell membrane receptors and thus affected absorption

drug-diet interactome map and thus to identify, predict, and prevent possible unwanted interactions between natural compounds and drugs [19]. Preventive measures that include daily intake of micronutrients, accorded to health authorities' recommendations [20], supplementation of the elements in lack, and long-term fortification programs for populations at risk can prevent and restore the related deficiencies. In addition, high-risk patients (elders, obese, critically ill, with chronic diseases, with known genetic variants in drug transporters, receptors, or enzymes) and individuals under high-risk medication (antimicrobials, antiepileptics, warfarin, drugs with narrow therapeutic index) should be targeted for DNI monitoring $[15,16]$. The physician's decision to screen for MNDs should be based on the patient's history, comorbidities, dietary habits, and lifestyle. The aim of personalized medicine is the tailoring of health-care services to the needs of the individual patient and/or to the person-at-risk by the evaluation of integrated health data (family history, medical data, -omics profiles) $[16,17,21]$. Such holistic strategies can be applied and support appropriate drug prescribing and nutritional advices, in order to minimize DNIs and MNDs, reduce health-care utilization and costs, and enhance well-being.

\section{Abbreviations}

MNDs: micronutrient deficiencies; DNIs: drug-nutrient interactions; PPPM: Predictive, Preventive, and Personalized Medicine. 


\section{Competing interests}

The authors declare that they have no competing interests.

\section{Authors' contributions}

All authors contributed equally to this manuscript, with the first suggestion by GB.

\section{Acknowledgements}

This review letter was a voluntary work from all contributed authors, without any financial support.

\section{Author details}

${ }^{1}$ Koropi Health Centre, 19400 Attica, Greece. ${ }^{2}$ Proteomics Research Unit

Biomedical Research Foundation of the Academy of Athens, Athens, Greece.

Received: 27 February 2016 Accepted: 20 April 2016

Published online: 12 May 2016

\section{References}

1. Jackson MJ. Diagnosis and detection of deficiencies of micro- nutrients: minerals. Br Med Bull. 1999;55:634e42.

2. Bailey RL, West Jr KP, Black RE. The epidemiology of global micronutrient deficiencies. Ann NutrMetab. 2015;66(2):22-33.

3. Samaras D, Samaras N, Lang PO, Genton L, Frangos E, Pichard C. Effects of widely used drugs on micronutrients: a story rarely told. Nutrition. 2013; 29(4):605-10.

4. Kaganov B, Caroli M, Mazur A, Singhal A, Vania A. Suboptimal micronutrient intake among children in Europe. Nutrients. 2015;7(5):3524-35.

5. Boerner P. Functional intracellular analysis of nutritional and antioxidant status. J Am Nutraceut Assoc. 2001;4:27-40.

6. von Arnim CA, Dismar S, Ott-Renzer CS, Noeth N, Ludolph AC, Biesalski HK Micronutrients supplementation and nutritional status in cognitively impaired elderly persons: a two-month open label pilot study. Nutr J. 2013;12:148.

7. Damms-Machado A, Weser G, Bischoff SC. Micronutrient deficiency in obese subjects undergoing low calorie diet. Nutr J. 2012;11(1):34.

8. Gröber U. Interactions between drugs and micronutrients. Med Monatsschr Pharm. 2006:29(1):26-35.

9. Gunturu SG, Dharmarajan TS. Drug-nutrient interactions. In: Pitchumoni CS Dharmarajan TS, editors. Geriatric gastroenterology. New York: Springer; 2012. p. 89-98.

10. Mallet $L$, Spinewine A, Huang A. The challenge of managing drug interactions in elderly people. Lancet. 2007;370(9582):185-91.

11. Sorenson JM. Herb-drug, food-drug, nutrient-drug and drug-drug interactions: mechanisms involved and their medical implications. J Altern Complement Med. 2002;8(3):293-308

12. Chan L-N. Drug-nutrient interactions. J Parenter Enter Nutr. 2013;37(4):450-9.

13. Boullata Jl. Drug and nutrition interactions: not just food for thought. J Clin Pharm Ther. 2013:38(4):269-71.

14. Thurnham DI. An overview of interactions between micronutrients and of micronutrients with drugs, genes and immune mechanisms. Nutr Res Rev. 2004;17(2):211-40

15. Boullata Jl, Hudson LM. Drug-nutrient interactions: a broad view with implications for practice. J Acad Nutr Diet. 2012;112(4):506-17.

16. Sadkovsky IA, Golubnitschaja O, Mandrik MA, Studneva MA, Abe H. PPPM (Predictive, Preventive and Personalized Medicine) as a new model of the national and international healthcare services and thus a promising strategy to prevent a disease: from basics to practice. Int J Clin Med. 2014;5:855-70.

17. Golubnitschaja O, Costigliola V, EPMA. General report \& recommendations in Predictive, Preventive and Personalised Medicine 2012: white paper of the European Association for Predictive, Preventive and Personalised Medicine. EPMA J. 2012;3(1):14.

18. Ghosh D, Skinner M, Laing W. Pharmacogenomics and nutrigenomics: synergies and differences. Eu J Clin Nutr. 2007;61(5):567-74.

19. Jensen K, Ni Y, Panagiotou G, Kouskoumvekaki I. Developing a molecular roadmap of drug-food interactions. PLoS Comput Biol. 2015;11(2):1-15.

20. European Commission Scientific Committee on Food. Opinion of the scientific Committee on Food on the revision of reference values for nutrition labelling, Commission of the European Communities. Brussels, Belgium. 2003.http://ec. europa.eu/food/fs/sc/scf/out171_en.pdf. Accessed 14 Feb 2016.

21. Lemke HU, Berliner L. Patient specific modeling and model guided therapy. EPMA J. 2011;2:181-2.

\section{Submit your next manuscript to BioMed Central and we will help you at every step:}

- We accept pre-submission inquiries

- Our selector tool helps you to find the most relevant journal

- We provide round the clock customer support

- Convenient online submission

- Thorough peer review

- Inclusion in PubMed and all major indexing services

- Maximum visibility for your research

Submit your manuscript at www.biomedcentral.com/submit 